\title{
Advances in Precision Coffee Growing Research: A Bibliometric Review
}

\author{
Lucas Santos Santana ${ }^{1} \mathbb{1}$, Gabriel Araújo e Silva Ferraz ${ }^{1}{ }^{\mathbb{C}}$, Alberdan José da Silva Teodoro ${ }^{2}$, \\ Mozarte Santos Santana ${ }^{3}$, Giuseppe Rossi ${ }^{4}\left[\right.$ and Enrico Palchetti ${ }^{4, *}$
}

1 Agricultural Engineering Department, Federal University of Lavras, P.O. Box 3037, Lavras 37200-000, Brazil; lucas.unemat@hotmail.com (L.S.S.); gabriel.ferraz@ufla.br (G.A.e.S.F.)

2 Department of Administration and Economics, Federal University of Lavras, P.O. Box 3037, Lavras 37200-000, Brazil; alberdan.teodoro@estudante.ufla.br

3 Institute of Natural Sciences, Federal University of Lavras, P.O. Box 3037, Lavras 37200-000, Brazil; ss.mozarte@gmail.com

4 Department of Agriculture, Food, Environment and Forestry (DAGRI), University of Florence, Via San Bonaventura, 13, 50145 Florence, Italy; giuseppe.rossi@unifi.it

* Correspondence: enrico.palchetti@unifi.it

check for

updates

Citation: Santana, L.S.; Ferraz, G.A.e.S.; Teodoro, A.J.d.S.; Santana,

M.S.; Rossi, G.; Palchetti, E. Advances in Precision Coffee Growing Research: A Bibliometric Review. Agronomy 2021, 11, 1557. https://doi.org/ 10.3390/agronomy11081557

Academic Editors: Francisco

Manzano Agugliaro and

Esther Salmerón-Manzano

Received: 30 June 2021

Accepted: 1 August 2021

Published: 5 August 2021

Publisher's Note: MDPI stays neutral with regard to jurisdictional claims in published maps and institutional affiliations.

Copyright: (c) 2021 by the authors. Licensee MDPI, Basel, Switzerland. This article is an open access article distributed under the terms and conditions of the Creative Commons Attribution (CC BY) license (https:// creativecommons.org/licenses/by/ $4.0 /)$.
Abstract: Precision coffee-growing technologies contribute to increased yield, operational efficiency, and final product quality. In addition, they strengthen coffee growing in the global agricultural scenario, which makes this activity increasingly competitive. Scientific research is essential for technological development and offering security regarding its application. For relevant research identification, bibliometric revision methods expose the best studies and their relationships with countries and authors, providing a complete map of research directions. This study identified the main contributions and contributors to academic research generation about precision coffee growing from 2000 to 2021. Bibliometric analysis was performed in VOSViewer software from the referential bases Scopus and Web of Science that identified 150 articles. Based on the number of citations, publications about precision coffee-growing showed Brazilian institutions at the top of the list, and Brazil's close relationships with North American and South African institutions. Geostatistical analysis, remote sensing and spatial variability mapping of cultivation areas were used in most experimental research. A trend in research exploring machine learning technologies and autonomous systems was evident. The identification of the main agents of scientific development in precision coffee growing contributes to objective advances in the development and application of new management systems. Overall, this analysis represents wide precision coffee growing research providing valuable information for farmers, policymakers, and researchers.

Keywords: precision agriculture; analysis; bibliometry; coffee farm; systematic review

\section{Introduction}

Coffee growing is among the primary agricultural activities in the world [1,2]. It represents an essential source of income for many countries [3,4]. Coffee is produced in about 60 countries, where tropical regions favor its development. Countries like Brazil, Vietnam and Colombia are the main world producers [5].

High rates of coffee yield result from application of technological practices during production and processing stages. Modern agriculture is characterized by the rapid expansion of information technologies arising from monitoring and control of storage, organization and agricultural activities [6]. Using techniques and technologies aimed at high levels of productivity combined with sustainability is known as precision agriculture [7]. Precision agricultural practical can maximize the potential of each region, making the crop more productive and favoring cost reduction [8].

Technological advances in precision agriculture contribute to obtaining accurate and reliable measurements in a crop. This can facilitate monitoring edaphoclimatic variables 
on a more accurate scale. Thus, designing fertilization plans, seedling selection and agricultural activities make agricultural production more effective [9]. Smart agriculture is crucial to maximizing crop yields and revenues and preserving natural resources [10].

Technologies drive the creation and segmentation of specific classes of precision agriculture. In coffee crops, such technological approaches are known as precision coffee growing. Alves et al. [11] described precision coffee growing as a set of techniques aimed at optimizing agricultural input (fertilizers, correctives, seeds and pesticides) in a function of spatial and temporal variability of factors associated with the ecosystem (water, soil, plant). Recently Kouadio et al. [12] described precision coffee growing as optimization of agricultural inputs (fertilizers, corrective and defensive) related to spatial and temporal variability of factors associated with the water-soil-plant and atmospheric system.

Crop coffee is cultivated mainly by small farmers, contributing to the low implementation of technology in the field, due to the absence of technical and financial inputs and pilot projects. The practical application in precision agriculture techniques was variable rate distribution, initially used in annual crops and adapted to other crops. Generally, cultures that depend on specific equipment for handling use solutions designed for other cultures, and these adaptations can take years.

The insertion of efficient precision coffee techniques in coffee crops can be found in many studies. When evaluating the transversal application of variable rate fertilizers, Andrade et al. [13] defined optimal lateral fertilizer distribution, and created an efficient and practical method for this type of analysis. Mapping plant attributes in a coffee crop, Ferraz et al. [14], demonstrated the importance of this mapping category for coffee crop management. Using aerial image obtained by remotely piloted aircraft, Santos et al. [15] proposed methods for estimating coffee biophysical parameters. Barros et al. [16] evaluated the operational performance of a fertilizer distribution system. These are some of the practical contributions in the literature.

Evaluating publications about precision coffee growing allows the analysis of studies carried out from planting to a producing the final product. Analyzing trends in research, perspectives and contributions of different actors is essential for assessing scientific literature concerning the development of precision coffee growing. Using techniques applied to literature reviews can create an overview of the subject. Applications of systematic reviews in agriculture are recent but have been shown to be effective in synthesizing knowledge about agricultural literature and indicating priorities for future research [17].

Making systematic reviews allows the selection of studies about a specific topic or interest area, highlighting what is already known and exposing future opportunities [18,19]. These studies establish explicit and rigorously applied criteria, facilitating their later reproduction [20]. Systematic reviews aim to answer a specific research question with a particular search strategy and a literature synthesis presentation [21]. It is essential to emphasize the criteria adopted during a systematic review to minimize bias or personal influences of the researcher in the results [22].

During the research process, scholars are interested in finding publications most relevant in a study area. Thus, researchers use citation tracking to identify the most relevant articles or journals for a particular area [23]. The bibliometric analysis technique contributes to searches by considering the differences between articles by levels of relevance [24,25].

Citation number, publication volume and relevant journals, among other categories, facilitate the scientific diagnosis of a specific area study [26]. Bibliometric analysis makes it possible to identify dynamics and possible trends in scientific production [27]. This method organizes the existing literature, showing its publications trajectory as well as traditional and emerging fields of research [28,29].

There are some bibliometric studies on agriculture in the scientific literature. Among them, Pallottino et al. [30] reported the importance of studies involving precision agriculture over a twenty year period, while Velasco-Muñoz et al. [31] portrayed global research about rainwater use concerning applications in irrigation systems for conservation and sustainability strategies. In another study that used bibliometrics with modeling topic, 
Kane et al. [32] mapped research about perennial cultures by four scientific research bases. However, no bibliometric studies exist concerning issues related to precision coffee growing.

Mapping research about precision coffee growing has become important, given the significant technological advances reported in several studies carried out at different coffee cultivation stages. Identifying the most important literature about precision coffee growing can facilitate referential search processes and the identification of theoretical premises for future studies.

Given this importance, the objective of this study was to identify the main contributions of studies, researchers, entities and countries, most relevant in academic research about precision coffee growing over the last 20 years by exploring the referential bases Scopus and Web of Science. The results of this study may provide insights into research trends and contribute to research and scientific production practices.

\section{Research Methodology}

The evolution of precision coffee growing in scientific publications was evaluated by bibliometric analysis according to the procedures described in Figure 1. Bibliometric studies allow identification of possible theoretical trends, intellectual structures of a discipline or study area $[33,34]$. The work sequence in a bibliometric analysis is divided into data recovery, preprocessing, network extraction, normalization, mapping and visualization analysis $[35,36]$.

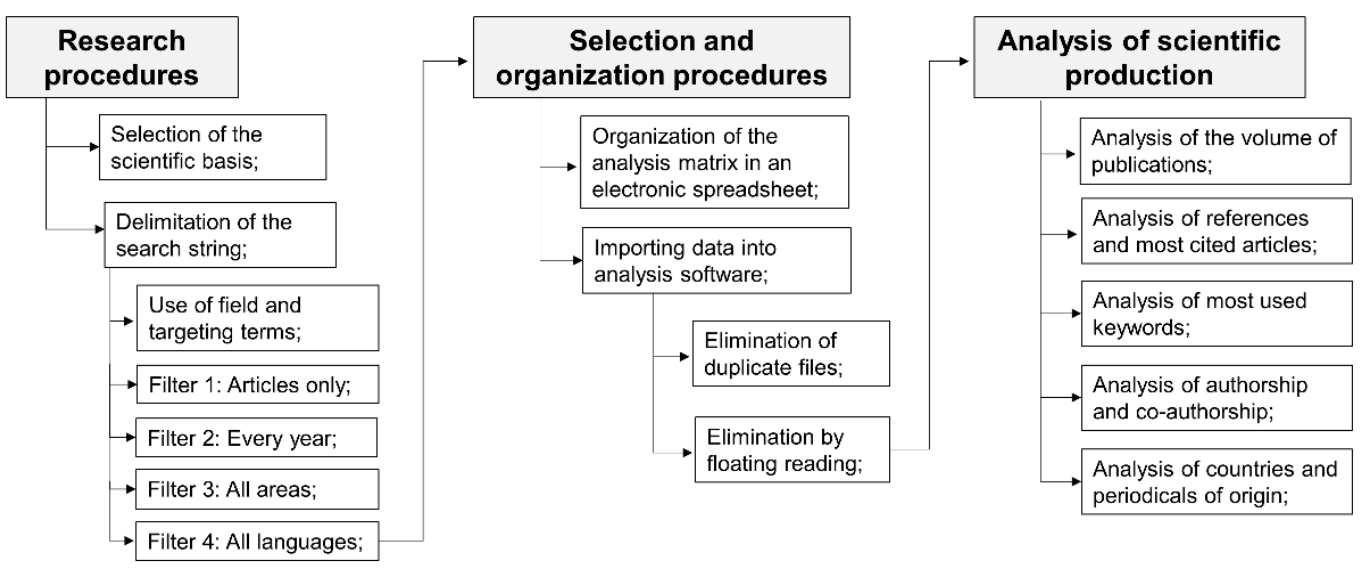

Figure 1. Processes systematization for bibliometric analysis.

\subsection{Research Procedure}

Scopus and Web of Science were selected for conducting the searches, aiming at a representative metadata content. The use of Scopus and Web of Science bases, due to their relevance in bibliometric studies, was a necessary prerequisite [37]. Searches in different scientific bases are essential for correct interpretation and bibliometric indicator use in scientific research evaluation [38,39]. Scientific approaches that adopted bibliometric analysis on other themes used at least one of these bases [40].

When starting a bibliometric analysis, it is necessary to define the search terms to eliminate the generalization of the results. For this, the series of key terms should be not be too restrictive but sufficient to include only the topics of related studies [41]. Precision farming practices aimed at growing coffee are called "precision coffee farming" [11]. This definition contributes to string delimitation, selecting key terms and filtering only those files that depict precision agriculture in coffee culture. The key terms used were "spatial variability", "precision agriculture", "remote sensing", "soil mapping", "RPA", "UAV", "UAS" and "variable rate". Only publications that contained the key terms in the title, abstract or keywords were used. 
In SCOPUS, the string TITLE-ABS-KEY (coffee) AND TITLE-ABS-KEY ("spatial variability" OR "precision agriculture" OR "remote sensing" OR "soil mapping" OR "RPA" OR "UAV" OR "UAS" OR "Variable rate") was used. In the WEB OF SCIENCE (WOS) database, the string was TS = (Coffee) AND TS = ("precision agriculture" OR "spatial variability" OR "remote sensing" OR "soil mapping" OR "RPA" OR "UAV" OR "UAS" $\mathrm{OR}$ "Variable rate"). Searches were not restricted in terms of academic area or languages. However, the selection of the document was restricted to articles published between 2000 and 2021/1st semester.

\subsection{Selection and Organization Procedures}

Selection and organization process consisted of reviewing the bibliometric data obtained. The searches resulted in 449 documents, 253 papers in Scopus and 196 papers in Web of Science. The next step was to remove duplicate articles because searches with similar parameters can find the same article. Then, documents were submitted to reading the abstracts and verifying similarity with the research theme. After these selections, 299 articles were excluded and 150 articles were chosen for use in this study.

Data were organized in an electronic spreadsheet and imported into VOSviewer bibliographic analysis software for identification and bibliometric networks analysis. VOSviewer is software for constructing and visualizing bibliometric networks. These networks can include journals, researchers and individual publications built on citation, bibliographic coupling, cocitation or coauthorship relationships [42]. In addition, they offer text mining functionality used in the construction and visualization of networks and co-occurrences of terms extracted from scientific literature [43].

\subsection{Bibliometric Mapping and Clustering}

Based on a multidimensional mapping technique VOSviewer locates the words in a dimensional space, portraying the distance between items according to their similarity. Results are presented in circle form, representing items found in the survey. These items are clustered and represented by color, forming a bibliometric map [44].

Quality criteria for research and journals are citations and scientific impact, as reported by Merton [45]. This rule was used for bibliometric mappings, which took account of annual evolution of publications and citations, leading researchers, most influential countries in publications related to this field, most notable journals, most relevant authors, main keywords used by authors, main keywords found in the most important publications, universities, entities related to these topics, the main areas of knowledge involved, and the trends and terms that indicate future lines of research.

\section{Results and Discussion}

\subsection{Evolution of Publications}

Bibliometric analyses found 150 articles about the precision management of coffee growing from 2000 to $2021 / 1$ st sem. The evolution of these publications is shown in Figure 2, illustrating the publications for each year.

Precision coffee research is relatively recent, as the first research found in a journal database was from 2004. This initial step in coffee research was performed by Herwitz et al. [46]. Although it was published in 2004, the experiments were carried out in 2002.

Four publications were found in the first years (2000 to 2006). Two articles were published in 2004 by the Herwitz and Johnson research groups, who used the same equipment and experimental field. In an analysis based on unmanned aerial vehicle (UAV) application to monitoring coffee trees, the authors advanced an essential step towards monitoring coffee fields by UAVs. Despite the pioneering nature of this technology in coffee growing, this type of analysis was not adopted by research groups in the coming years. The first hypothesis was related to the impossibility of carrying out similar experiments, because of high costs and few image capture and processing resources. 


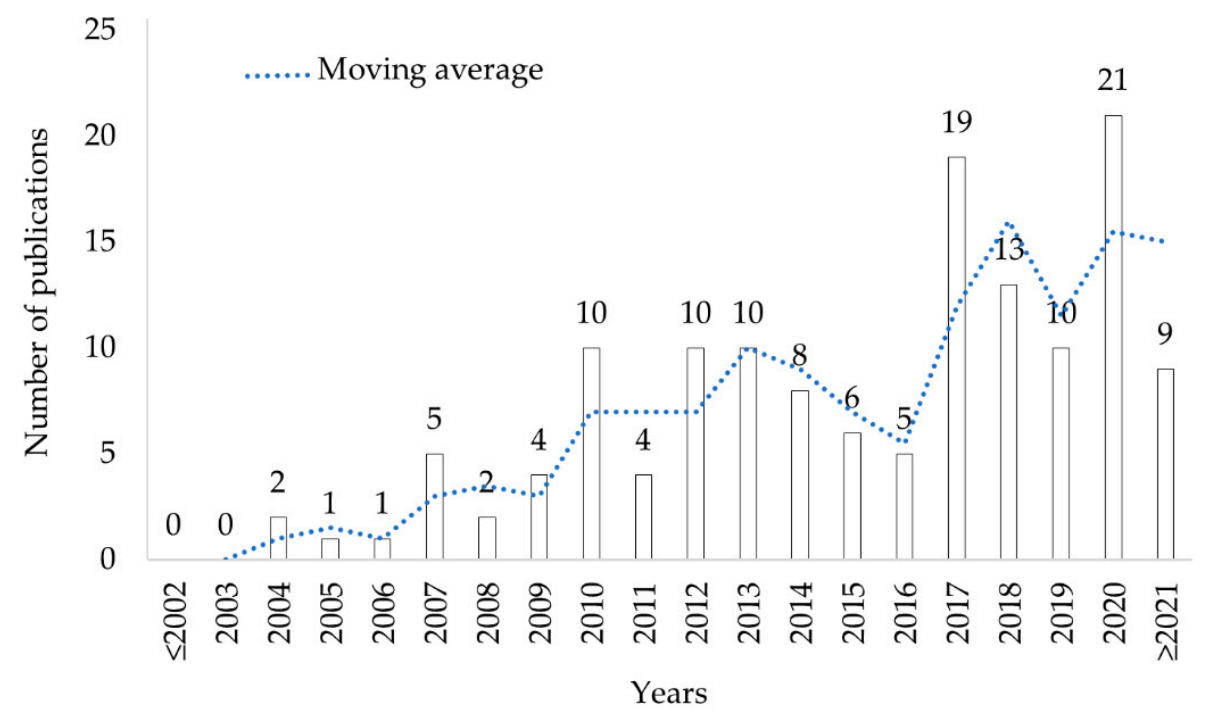

Figure 2. Evolution in precision coffee growing research publications from 2000 to 2021 / 1 st sem.

In the following years, there was a significant increase in publications. From 2007 to 2013, most articles identified referred to spatial variability. During the period, essential discoveries were identified about variability, primary nutrient behavior and new ways of collecting soil for analysis.

A significant increase in research about precision coffee-growing demonstrated the coffee industry's interest in technological advances. Studies on the application of precise techniques in coffee management over the years have changed the technicians' and farmers' perceptions about coffee-growing. The development of such research is closely related to technological advances in agriculture. An important trend of publications on precision agriculture was presented in the research by Pallottino et al. [30], where a linear growth of publications about precision agriculture between 2000 and 2016 was demonstrated. When analyzing the academic progress of the precision coffee growing theme, a reduction in the number of publications between the years 2013 and 2016 stands out. These different publications concern the themes of "precision agriculture" and "precision coffee-growing" and how they may be related to a crop's characteristics, since in perennial crops, like coffee, vegetative development is reduced, making it time-consuming to obtain data compared to annual crops.

Another important aspect is the amount of research on the same topic. In some cases, the apparent research possibilities are exhausted in a few years. This may have happened in research related to the mapping of soil spatial variability in coffee crops, which led to a volume reduction in publications after 2013 and returning to a high level in 2017.

From 2017 onwards, the publication of articles on precision coffee growing showed a significant increase due to the application of new technologies in agriculture. The main finding after 2017 was the use of remote sensing for monitoring coffee production. In this period, the use of images obtained by Remotely Piloted Aircraft (RPA) was systematically explored.

\subsection{Relevant Publications and Characteristics of Papers}

Among the 150 files analyzed, ten papers were selected that stood out for having more than 20 citations from 2000 to 2021/1st sem (Table 1). The most cited author in the 20 years of analysis was Herwitz et al. [46]. This is due to the high level of technology used in the experiment available at the time. Furthermore, the authors' findings were applied again with the advent of UAVs in agriculture. The great impact of the research also is related to the journal in which it was published. Computers and Electronics in Agriculture journal is an important journal in agriculture. 
Table 1. Top 20 publications scientific on precision coffee growing from 2000 to $2021 / 1$ st sem, ranked by citation number.

\begin{tabular}{|c|c|c|c|c|c|}
\hline $\mathbf{R}$ & Title & Authors & PY & Journal & $\mathrm{NC}$ \\
\hline $1^{\circ}$ & $\begin{array}{l}\text { Imaging From An Unmanned Aerial Vehicle: } \\
\text { Agricultural Surveillance And Decision Support }\end{array}$ & Herwitz, et al. [46] & 2004 & $\begin{array}{l}\text { Computers and Electronics in } \\
\text { Agriculture }\end{array}$ & 277 \\
\hline $2^{\circ}$ & $\begin{array}{l}\text { Separability Of Coffee Leaf Rust Infection Levels } \\
\text { With Machine Learning Methods At Sentinel-2 Msi } \\
\text { Spectral Resolutions }\end{array}$ & Chemura, et al. [47] & 2017 & Precision Agriculture & 45 \\
\hline $3^{\circ}$ & $\begin{array}{l}\text { Spatial Variability Of Leaf Wetness Duration In } \\
\text { Different Crop Canopies }\end{array}$ & Sentelhas, et al. [48] & 2005 & $\begin{array}{l}\text { International Journal of } \\
\text { Biometeorology }\end{array}$ & 45 \\
\hline $4^{\circ}$ & $\begin{array}{l}\text { Spatial Variability Of Chemical Attributes And } \\
\text { Productivity In The Coffee Cultivation }\end{array}$ & Silva ${ }^{2}$, et al. [49] & 2007 & Ciencia Rural & 40 \\
\hline $5^{\circ}$ & $\begin{array}{l}\text { Spatial Variability Of Chemical Attributes And } \\
\text { Coffee Productivity In Two Harvests }\end{array}$ & Silva ${ }^{2}$, et al. [50] & 2008 & Ciencia e Agrotecnologia & 41 \\
\hline $6^{\circ}$ & $\begin{array}{l}\text { Spectral Analysis And Classification Accuracy Of } \\
\text { Coffee Crops Using Landsat And A } \\
\text { Topographic-Environmental Model }\end{array}$ & $\begin{array}{l}\text { Cordero-Sancho and } \\
\text { Sader [51] }\end{array}$ & 2007 & $\begin{array}{l}\text { International Journal of } \\
\text { Remote Sensing }\end{array}$ & 38 \\
\hline $7^{\circ}$ & $\begin{array}{l}\text { Spatial Variability Of Chemical Attributes Of An } \\
\text { Oxisol Under Coffee Cultivation }\end{array}$ & Silva ${ }^{1}$, et al. [52] & 2010 & $\begin{array}{l}\text { Revista Brasileira de Ciencia } \\
\text { do Solo }\end{array}$ & 36 \\
\hline $8^{\circ}$ & $\begin{array}{l}\text { Geostatistical Analysis Of Fruit Yield And } \\
\text { Detachment Force In Coffee }\end{array}$ & Ferraz, et al. [53] & $2012 a$ & Precision Agriculture & 33 \\
\hline $9^{\circ}$ & $\begin{array}{l}\text { Feasibility Of Monitoring Coffee Field Ripeness } \\
\text { With Airborne Multispectral Imagery }\end{array}$ & Johnson, et al. [46] & 2004 & $\begin{array}{l}\text { Applied Engineering in } \\
\text { Agriculture }\end{array}$ & 32 \\
\hline $10^{\circ}$ & $\begin{array}{l}\text { Spatial And Temporal Variability Of Phosphorus, } \\
\text { Potassium And Of The Yield Of A Coffee Field }\end{array}$ & Ferraz, et al. [54] & $2012 b$ & Engenharia Agricola & 31 \\
\hline
\end{tabular}

R: Ranking; Silva ${ }^{2}$ : Silva F.M.; Silva ${ }^{1}$ : Silva S.D.A; PY: Publication Year and NC: Number of citations.

The most cited study, Herwitz et al. [46], demonstrated the positive aspects of agricultural areas monitored by unmanned aerial vehicles (UAV). The study described field data from combinations of red and infrared image aerial images, resulting in the definition of higher productivity zones, attesting to the efficiency of aerial remote sensing for agricultural monitoring with orbital imaging applications. Despite being published 16 years ago, this research is still used as a basis for various agricultural applications due to the nature of the techniques used.

Advances in remote sensing have been observed in coffee management. Relevant analyses about this technology are described in research by Chemura et al. [47]. The authors evaluated applications of a Sentinel 2 sensor combined with Random Forest (RF) algorithms in the evaluation of coffee leaf rust (CLR) fungus, and demonstrated through vegetation indices the potential of remote sensing applications in identifying and discriminating levels of this fungus.

Among the most cited publications, the research developed by Sentelhas et al. [48] presented reliable methods for monitoring the duration of leaf wetness. Their results were based on installing sensors at different heights and evaluation by geometric mean regression. These results made important contributions to accurate precision irrigation practices and microclimate monitoring and evidenced spatial variability in the duration of wetness by rain, dew, and irrigation.

Pioneering various applications in coffee growing, Silva ${ }^{2}$ et al. [49] characterized the spatial variability of chemical attributes of soil by georeferenced sampling and geostatistical techniques. Using the same experimental field, $\mathrm{Silva}^{2}$ et al. [50] evaluated productivity of the 2002/2003 and 2003/2004 coffee harvests in georeferenced grids of $25 \times 25 \mathrm{~m}^{2}$. The data obtained were sufficient for geostatistical analysis such as semivariogram adjustments and kriging interpolation. In this study, the researchers defined the spatial dependence of chemical attributes and coffee crop yield. Silva's research clarified the wide range of soil chemical attributes justifying the study of variable rate fertilizer application in coffee plantations, which in one the best discoveries about the spatial variability of soil in coffee cultivation.

Among the most cited research, an article by Cordero-Sancho, Sader [51] contributed to precision coffee growing development using remote sensing technologies. Using Landsat 
satellite images combined with geoprocessing techniques, the authors defined optimal regions for growing coffee, which was the first of several analyzes on remote sensing applications in spatial variability for coffee growing.

Regarding mapping studies of soil variability in coffee culture, Silva ${ }^{1}$ et al. [52] evaluated the main chemical attributes including available $\mathrm{P}, \mathrm{Na}$, and $\mathrm{S}$, exchangeable $\mathrm{Ca}$, $\mathrm{Mg}$ and $\mathrm{Al}, \mathrm{pH}, \mathrm{H}+\mathrm{Al}, \mathrm{SB}, \mathrm{t}, \mathrm{T}, \mathrm{V}, \mathrm{m}, \mathrm{MO}, \mathrm{ISNa}$, P-remnant and micronutrients $(\mathrm{Zn}, \mathrm{Fe}$, $\mathrm{Mn}, \mathrm{Cu}$ and B). Multivariate analysis techniques associated with geostatistics facilitated the assessment of soil variability. These authors demonstrated the applicability of mapping the behavior of these nutrients in the soil.

Equipment adjustments for mechanized harvesting operations in coffee farming require extensive information about plant physiology and anatomical factors. The paper of Ferraz et al. [53] used geostatistics to evaluate the detachment strength of coffee fruits in a study carried out on 22 hectares of Arabica coffee. The authors showed the possibility of detachment strength for characterizing spatial patterns of coffee fruits, classified as green or ripe by semivariogram and kriging. They found that exponential functions adjusted in the semivariogram described the structure and magnitude of spatial variation of release strength of green fruits and coffee yield.

Johnson et al. published in 2004 a pioneering article for monitoring coffee maturation by a UAV. It proposed a method to identify the coffee fruit maturation through reflectance in the aerial image. Field collections aggregated the results. The average maturation index per field was significantly correlated with soil-based counts recorded by the producer. This work is still the basis for research using aerial scenes to monitor coffee tree.

Using precision agriculture technologies, localized data collection, and geostatistical analysis techniques, Ferraz et al. [54] monitored chemical soil attributes during three consecutive harvests to optimize application of phosphorus and potassium. The study showed that semivariograms allow estimates of the spatial variability of soil chemical attributes, such as amounts of phosphorus and potassium, and their effects on coffee crop yield. This research complemented previous results on the relationship between spatial variability and yield.

The primary research related to precision coffee growing was mainly associated with soil variability (Table 1), but the essential contribution of remote sensing for the mapping of variability in the coffee crop is evident.

\subsection{Most Influential Journals}

Journals are ranked in order of importance by number of citations (Table 2). When analyzing the journals in Table 2, variations in their specificities were observed, but there was a predominance of journals with technological approaches. The journals "Computers and Electronics in Agriculture" and "Precision Agriculture" significantly contributed to technological development in agriculture. Pallottino et al. [30] carried out bibliometric research to demonstrate advances in precision agriculture and showed that the journals "Computers and Electronics in Agriculture" and "Precision Agriculture" predominate among the most important journals. A journal linked to remote sensing also appeared in this classification, indicating the potential use of this technology in coffee production.

Table 2. Top 6 sources of publications in word on precision coffee growing from 2000 to 2021/1st sem.

\begin{tabular}{|c|c|c|c|c|c|c|c|c|}
\hline $\mathbf{R}$ & Journal & SJR $^{1}$ & CiteScore $^{2}$ & $\mathrm{JCR}^{3}$ & $\mathbf{H}-\mathbf{i}$ & ISSN & ND & NC \\
\hline $1^{\circ}$ & Computers and Electronics in Agriculture [46] & 1.208 & 8.6 & 3.858 & 115 & 0168-1699 & 5 & 409 \\
\hline $2^{\circ}$ & Precision Agriculture [8-10] & 1.023 & 8.7 & 4.454 & 63 & $1385-2256$ & 9 & 398 \\
\hline $3^{\circ}$ & Revista Brasileira de Ciência do Solo [52] & 0.505 & 2.5 & 1.2 & 51 & 0100-0683 & 8 & 291 \\
\hline $4^{\circ}$ & Engenharia Agrícola [54] & 0.289 & 1.4 & 0.603 & 27 & $0100-6916$ & 11 & 256 \\
\hline $5^{\circ}$ & $\begin{array}{l}\text { IEEE Journal of Selected Topics in Applied } \\
\text { Earth Observations and Remote Sensing [8] }\end{array}$ & 1.246 & 7.2 & 3.827 & 88 & $1939-1404$ & 4 & 190 \\
\hline $6^{\circ}$ & Ciência e Agrotecnologia $[49,52]$ & 0.437 & 2.3 & 1.144 & 30 & $1413-70$ & 4 & 152 \\
\hline
\end{tabular}

\footnotetext{
${ }^{1}$ : Web of Science index, ${ }^{2}$ : Scopus index, ${ }^{3}$ : Scopus index, H-i: H index, ND: Number of documents and NC: Number of citations.
} 
Table 2 shows that the majority of the obtained journals are from Brazil, probably because of intensive coffee production in the country.

Even with greater inclusion in the best journals, the country does not occupy first place. This is due to the quality of the journals ( $\mathrm{H}$ index). The journals "Computers and Electronics in Agriculture" and "Precision Agriculture" are considered emerging in studies for technological application in agriculture as reported by [55]. It was observed that despite having fewer publications, these journals had a larger number of citations. This indicates high interest in searching for publications involving specialized applications in agriculture.

\subsection{Publications by Authors}

The H-index, which is obtained by the ratio of the number publications and their citations, was used to determine the author's impact on the topic of precision coffee growing. From the H-index values, the Scopus and WoS bases, and the volume of publications, the main authors of publications related to "precision coffee growing" were selected. Among the 186 identified, only 28 authors met the selection criteria established in the bibliometric selection methodology

According to established premises, Professor Fábio Moreira da Silva, from the Agricultural Engineering Department of Federal University of Lavras was the author with the greatest academic impact, with an H-Index of 12 (Scopus and WoS), 20 published documents and 303 citations, followed by Professor Gabriel Araújo e Silva Ferraz also from the Agricultural Engineering Department of Federal University of Lavras, with an H-index of 10 (Scopus) and 5 (WoS), 16 documents published and 203 citations. Details of the other authors can be seen in Table 3 .

Table 3. Top six relevant authors of publications on precision coffee growing from 2000 to 2021/1st sem.

\begin{tabular}{|c|c|c|c|c|c|c|}
\hline $\mathbf{R}$ & Authors & Id. & $\begin{array}{c}\text { H-i } \\
\text { (Scopus) }\end{array}$ & $\begin{array}{c}\mathrm{H}-\mathrm{i} \\
\text { (WoS) }\end{array}$ & NC & ND \\
\hline $1^{\circ}$ & Fábio Moreira da Silva [13-16,52] & Silva, F. M. & 12 & 12 & 303 & 20 \\
\hline $2^{\circ}$ & Gabriel Araújo e Silva Ferraz [6,13-15] & Ferraz, G. A. S. & 10 & 5 & 203 & 16 \\
\hline $3^{\circ}$ & Marcelo Silva de Oliveira $[14,50]$ & Oliveira, M. S. & 10 & 9 & 192 & 11 \\
\hline $6^{\circ}$ & Ivoney Gontijo [55] & Gontijo, I. & 6 & 6 & 139 & 8 \\
\hline $4^{\circ}$ & Julião Soares de Souza Lima [52] & Lima, J. S. S. & 11 & 10 & 129 & 9 \\
\hline $5^{\circ}$ & Samuel de Assis Silva [52] & Silva, S. A. & 11 & 5 & 117 & 9 \\
\hline
\end{tabular}

NC: Number of citations, ND: Number of documents, H-i: H index.

By identifying the main authors with documents indexed in the Scopus and WoS databases, the relationships among them were obtained. Only authors who had at least nine citations were selected. This criterion made it possible to classify the 44 authors shown in Figure 3.

The cocitation network is represented by circle charts, in which the size represents the author's influence, and the color of the circle represents the cluster (knowledge area) to which it was grouped. Therefore, it was possible to establish similarities, differences, relations and relevance between members that represent the intellectual base concerning the "precision coffee growing" theme.

By analyzing the cocitation network among the authors, three large clusters were determined. The first cluster, in green, is formed by the presence of three main researchers linked to Federal University of Lavras, with the largest volume of documents. Its main approaches refer to spatial variability of the coffee crop from an agricultural engineering perspective, such as collection network, variable rate application, and yield mapping. Numerical systems and models needed to support decisions about soil fertilization and agricultural management were also observed in this cluster (Figure 3).

In the second cluster, in red, the main focus funded in the research was soil attributes. These authors are linked to North American universities and their research covers topics that aim to understand the location of these nutrients in the soil and their physicochemical characteristics, aimed at better nutrient use and soil conservation. In this cluster, geo- 
statistical techniques for mapping spatial variability stand out. The use of geostatistical techniques in precision coffee growing was also observed in the bibliometric analyzes carried out by [56].

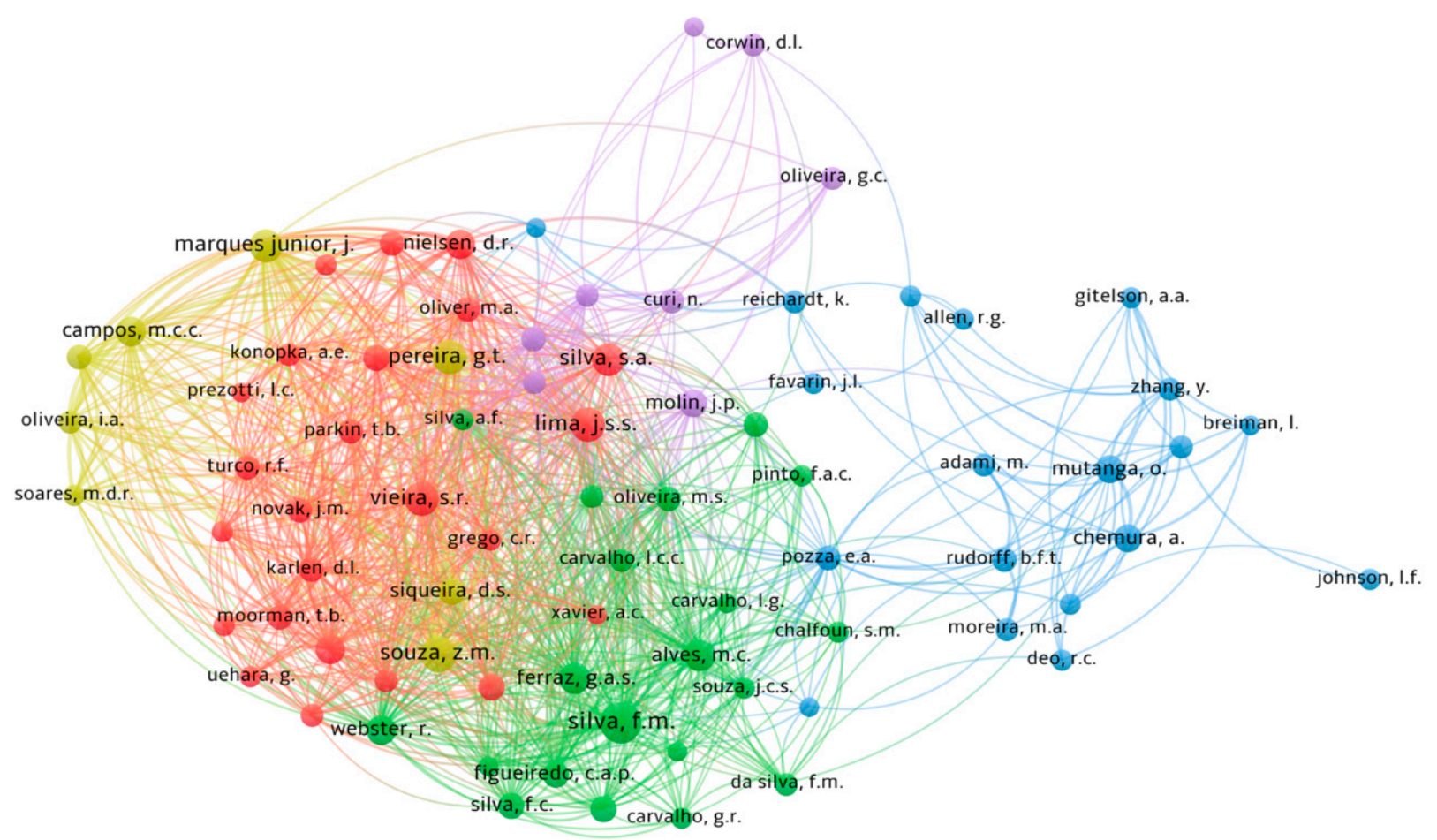

Figure 3. Scientific mapping of the cocitation of authors most relevance in precision coffee growing research. Red and yellow: Solo. Green: variable rate application and productivity mapping. Blue: remote sensing and Purple: plant nutritional status.

The researchers related to the third cluster, in blue, are characterized by research in coffee-growing by remote sensing analysis. Mapping coffee plantations by remote sensing aims to contribute to the identification of spatial variability using spectral responses [57].

\subsection{Most Influential Countries}

Evaluation of knowledge-producing nations on precision coffee-growing allowed them to be classified according to the number of citations over the years. Publications by country about "precision coffee growing" is shown in Figure 4. The main countries that produce the most scientific knowledge about precision coffee growing were identified. The predominance of Brazilian researchers in the top positions of publications by authors made Brazil the main country contributing to the development of precision coffee farming (Table 3). The 42 most impactful publications about precision coffee growing were carried out by Brazilian researchers.

The economic importance of coffee growing in Brazil, and the large number of research and teaching organizations related to coffee research in the country, impacts directly knowledge development about precision coffee growing. Brazil stands out as one of the countries with the highest investment in research and development in agriculture. These characteristics, associated with great territorial extension, has kept Brazil the leader in agricultural exports [58].

At the date of this study, Brazil is followed by countries such as the United States (four documents) and Colombia (three documents). The extensive presence of Brazilian researchers and journals also made Brazil the top country in producing scientific studies about precision coffee growing. 


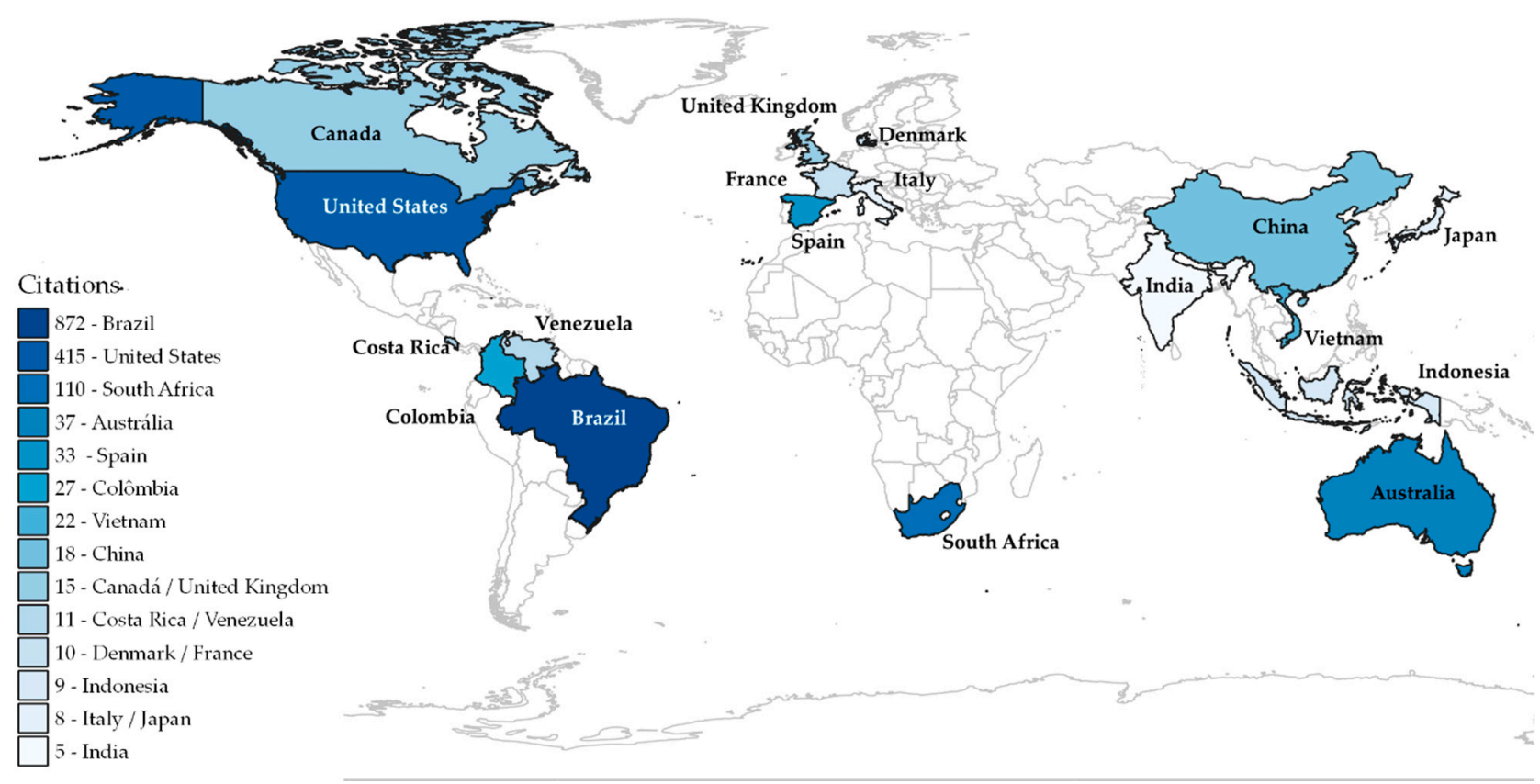

Figure 4. Number of citations by Country.

Although the cultivation of coffee in the United States is not expressive, this country is the second-largest producer of knowledge about precision coffee growing. This is due to the coffee area present in the Hawaii region, and the large number of educational and research organizations related to agricultural sciences in USA. It is important to highlight that pioneering work about precision coffee growing was carried out by Herwitz et al. [46] and Johnson, et al. [59], both in the American state of Hawaii (Figure 4).

\subsection{Organizations Related to Precision Coffee Growing' Research}

Identifying the organizations responsible for developing a knowledge area is of fundamental importance in biometric analysis, as it allows establishing trends and relationships between these organizations.

Research entities responsible for developing knowledge about precision coffee growing were identified. The relationships among scientific organizations that produce knowledge about this theme is presented in Figure 5. In this study, 31 organizations were highlighted with the highest volume of publications among 155 organizations identified and linked to authors (Figure 5).

Five groups were defined showing the great contribution of Brazilian universities in research development on precision coffee growing. The main institution was Federal University of Lavras, identified in the center region of the map in red. In the map, this university is linked with almost all other institutions. Directly or indirectly, this university shares research with institutions and internationals research centers, evidencing a strong relationship between Brazil and international institutions. The exchange of research within the country can be seen by the proximity between the red and blue groups, which occurs by the geolocation of these institutions. This geographic proximity facilitates the exchange of congresses and events.

Despite showing low association with each other, the grouping in green demonstrates the proximity between institutions from the United States of America and institutions from South Africa. In this grouping, a Brazilian university is seen as the "Federal University of Alfenas". This connection occurred due to the proximity of researchers to institutions in the United States of America and South Africa. 


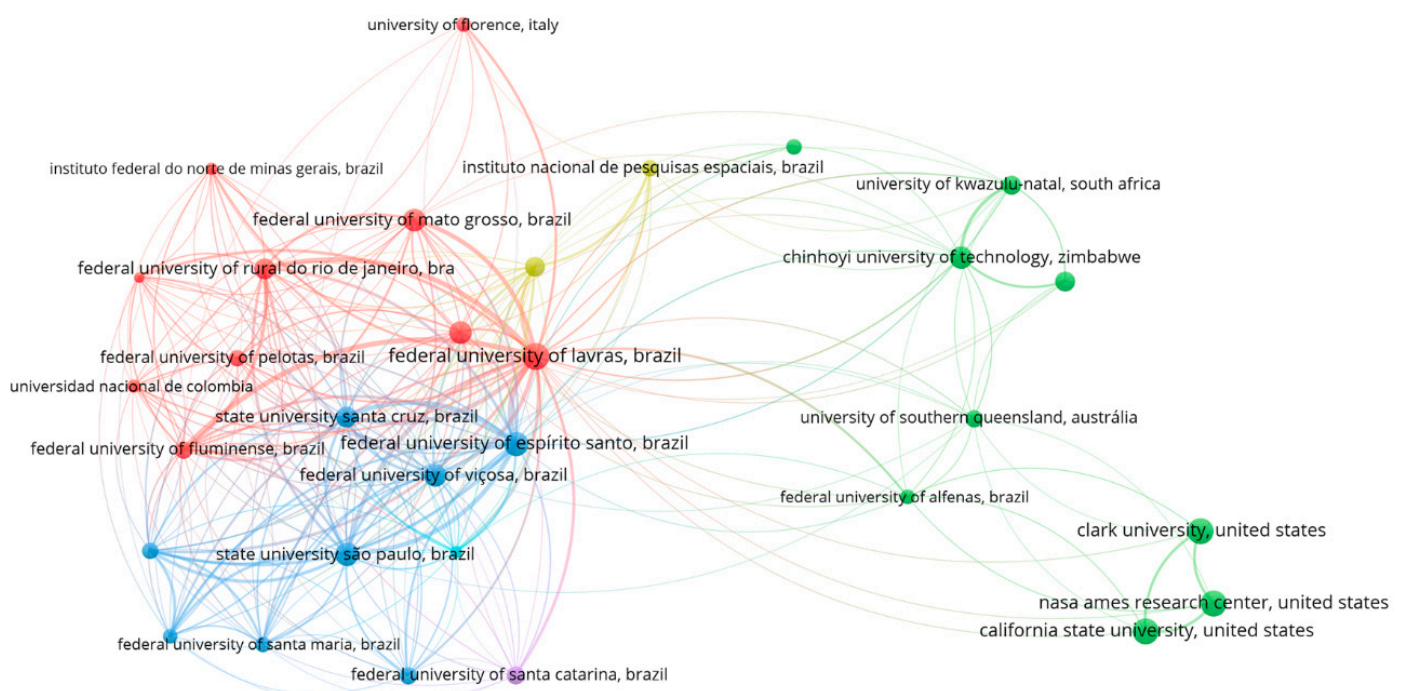

Figure 5. Scientific mapping network of educational and/or research organizations that produce knowledge about precision coffee growing. Red: the main institution was Federal University of Lavras. Yellow: "Company of technical as-sistance and rural extension of the state of Minas Gerais" and "National Institute for Space Research -I NPE". Green:proximity between institutions from the United States of America and institutions from South Africa. Blue:exchange of research within the country.

The group in yellow is represented by two institutions "Company of technical assistance and rural extension of the state of Minas Gerais" and "National Institute for Space Research -I NPE". Despite connections, this shows that these institutions follow different directions from Brazilian universities.

The analysis shows the relevance of Brazilian organizations in scientific research development about precision coffee growing, with emphasis on the Federal University of Lavras. A systematic bibliometric analysis of literature carried out by Cruz-O'Byrne et al. [60], showed the strong relationship of the Federal University of Lavras (UFLA) with coffee research. In searches performed on the Web of Science and Scopus databases, Pabon et al. [61], organized bibliometric data on coffee growing in which they also highlighted UFLA's contributions to scientific approaches to coffee crops.

The location of the Federal University of Lavras in the south of Minas Gerais state, a region with the largest coffee production in Brazil, contributed to UFLA assuming a very important role in coffee research. In the 2020 harvest, Minas Gerais produced more than $51 \%$ of national coffee production (Conab, 2020). The high productivity of this region, favored and driven by edaphoclimatic conditions, attracts researchers and installations concerning the coffee crop. Bibliometric studies about coffee growing presented by Sott et al. [56], highlighted Brazilian research dominance on coffee growing and its important role in agribusiness development.

\subsection{Keywords Related to Precision Coffee Growing}

Another way of investigating the study field is to analyze authors' keywords with the highest occurrence rates in all documents. In this phase, words with at least two occurrences are selected. Figure 6 presents analysis of cooccurrence of authors' keywords in analyzed documents.

Among 369 keywords identified in the studies, only 64 met adopted criteria. As a result, the "precision agriculture" term appeared most frequently, with 42 occurrences, followed by the terms "geostatistics" ( 40 occurrences), "remote sensing" (17 occurrences), "coffee" (14 occurrences), "Coffea arabica" (13 occurrences) and "spatial variability" (10 occurrences). In this figure it is possible to identify four distinct groups: red, representing technological applications; blue, analyses of canephore coffee; green, research related to monitoring of soil properties, and yellow, remote sensing applications. The 
groups have a strong connection with the areas of precision agriculture and geostatistics. This indicates that all applications for improvement in management are aimed at precise practices in coffee growing. The presentation of this map also contributes to searches for publications related to specific fields of precision coffee growing and how authors should organize their keywords for easy viewing.

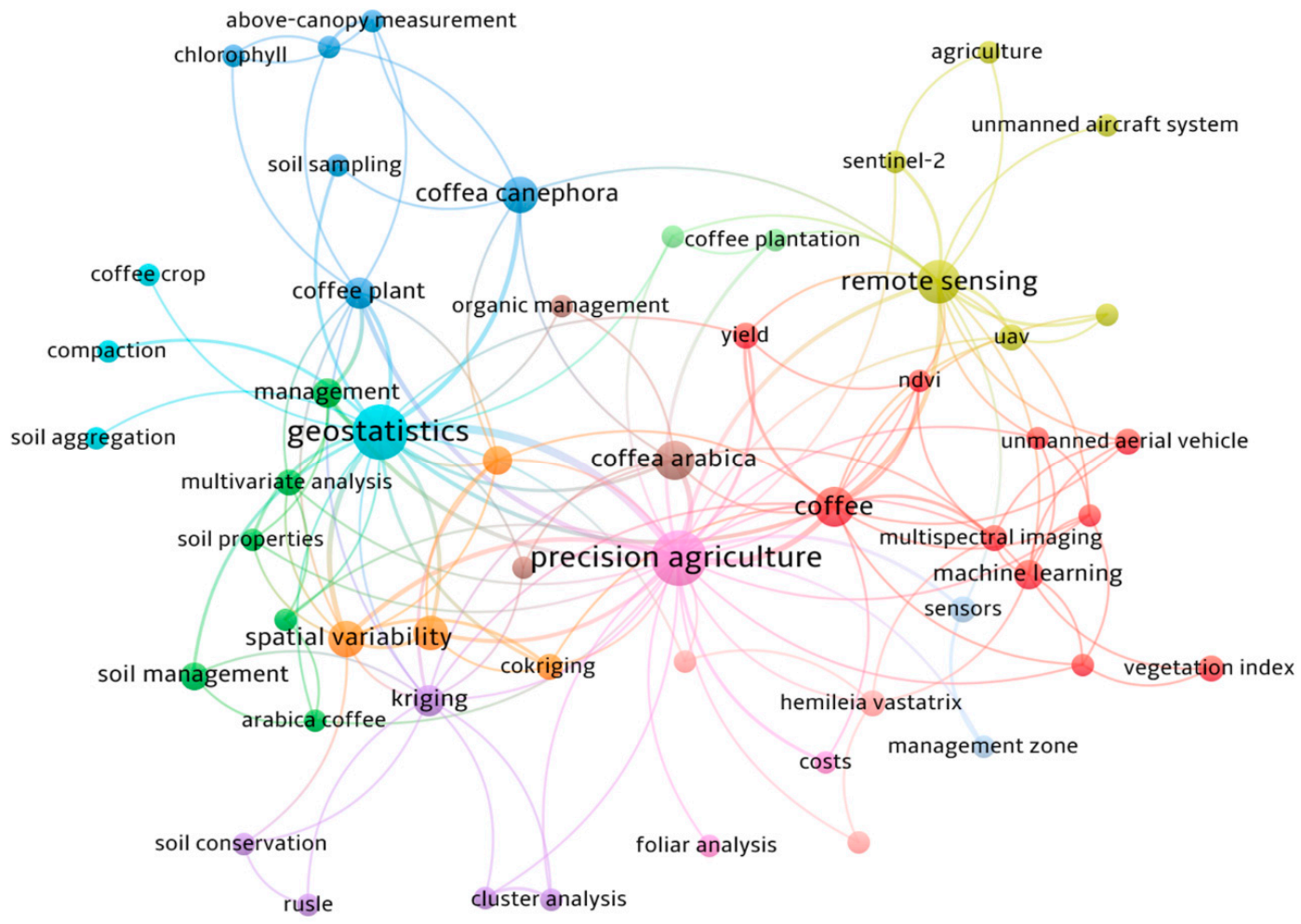

Figure 6. Map of network among author's keywords. Lines indicate co-occurrences between terms. Yellow: remote sensing. Red: remote sensing and machine learning. Green and purple: spatial variability of soil attributes. Azul: technologies applied to the cultivation of coffee canephora. Orange: application of techniques for mapping soil attributes.

\subsection{Trends in Precision Coffee Growing Research}

The surveys followed trends according to equipment availability, use of technologies and the value of theme to region. A map was created using a fractional counting method based on bibliographic data in the authors' keyword co-occurrences to understand trends (Figure 7). This map uses different colors to highlight the most commonly used author keywords over the last 20 years.

The information presented in Figure 7 demonstrates the characterization of predominant groups. Three prominent circles stood out: "precision agriculture", "remote sensing" and "geostatistic."

Precision agriculture appears as a trend in precision coffee growing. This occurs because techniques used in precision agriculture are tested in coffee growing, providing a basis for the development of several methods. From 2010 to 2020, there is a grouping in yellow colors and the relationship between "precision agriculture", "geostatistics", and "spatial variability" systematically explored at that time. The saturation of these keywords in searches began in 2018, making this technique well researched. In the following years, remote sensing techniques were again used with the advance of unmanned aerial vehicles. 


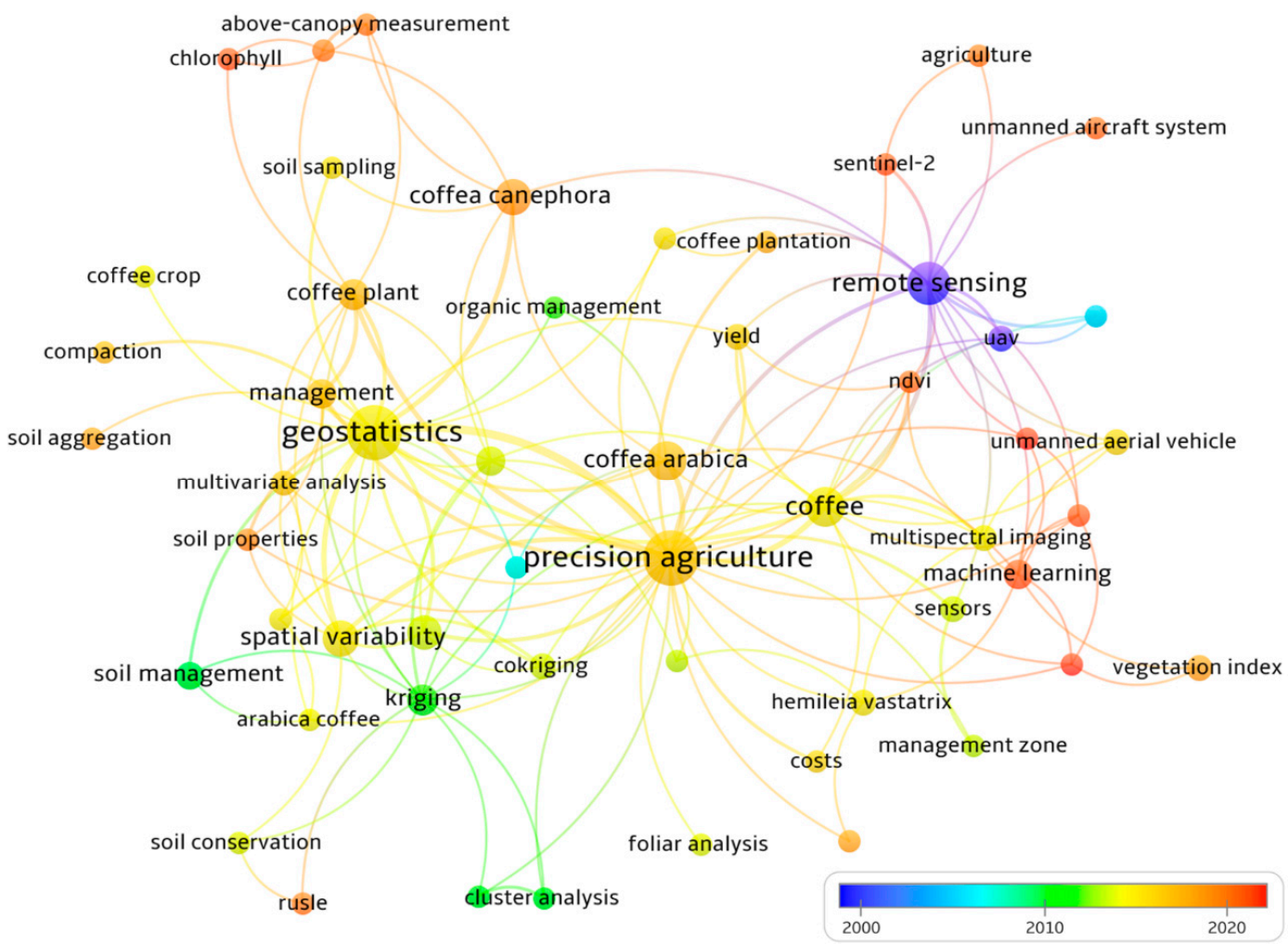

Figure 7. Map based on the co-occurrence of the authors' keywords and evolution from 2000 to $2021 / 1$ st sem. The color scale represents the year of keyword predominance.

Research related to remote sensing applications in precision coffee farming is considered pioneering. However, remote sensing technology has been exploited for the last 20 years and continues to be used. Figure 7 shows new trends in this technology, namely the words "multispectral imaging", "unmanned aerial vehicle", "ndvi", "sentinel" and "machine learning". The emergence of these trends is directly related to applications of remotely piloted aircraft (RPA) in agriculture, bringing to this field technological trends about machine learning.

New research involving precision coffee growing has explored automation profiles, aimed at improvements of crop management, such as mini sensors use to monitor coffee crops in real time [62], capacity evaluation of an Extreme Learning Machine (ELM) model when analyzing soil fertility properties, and the precise estimate of Robusta coffee yield [12]. Spatial determination of nitrogen content in coffee leaves has been made using remotely piloted aircraft, with machine learning techniques to classify aerial images [63]. Orbital sensors are used as a new methodology for obtaining maps about growth deficit (with up to $5 \mathrm{~cm}$ precision and $1 \mathrm{~m}$ spatial resolution), as well as the use of Differential Interferometric Synthetic Aperture Radar-D-InSAR [64].

\section{Conclusions}

Intellectual base analysis by bibliometric methods allowed evaluation of scientific evolution, research, and authorial references about precision coffee growing. It was possible to infer current conditions and trends regarding the research and scientific publication theme. The main countries, journals, scientific organizations, researchers, and cocitations networks with the greatest relevance about precision coffee growing were highlighted.

There has been a significant increase in scientific publications about precision coffee growing in the last 20 years (2000 to 2021/1st sem). This research solved essential obstacles in the sector and proposed sustainable management methods. The development of precision coffee growing was mainly marked by research to solve spatial variability in soils and 
plants, contributing to essentials technological advancements such as agricultural input application at a variable rate.

Among the most used technologies in precision coffee growing, remote sensing stands out. This knowledge area has contributed to coffee-growing development since initial research efforts. Furthermore, an emerging area with the advent of remotely piloted aircraft (RPA) has been developed.

The advance of technologies applied in precision coffee growing was demonstrated by keyword mappings in the most important scientific journals. The main keywords used in studies in recent years were "remote sensing," "machine learning," "vegetation index," and "remotely piloted aircraft", which demonstrates strong trends in automated applications using remote sensing technologies.

The development of this research is mainly linked to coffee-producing countries. Brazil's relevance to scientific knowledge development about precision coffee growing is evident since the country was the leader in terms of publication numbers about precision coffee growing. The Brazilian institution Federal University of Lavras (UFLA) was responsible for the origin of most studies. Most of the studies developed about precision techniques and practices adopted in coffee cultivation have been carried out in the last five years, culminating in the emergence of research produced by countries in the American, European, and African continents.

Supplementary Materials: The following are available online at https:/ / www.mdpi.com/article/10 .3390 /agronomy11081557/s1, supplementary file 1: scopus, WoS.csv; supplementary file 2: papers used in study.

Author Contributions: Conceptualization, L.S.S. and G.A.e.S.F.; methodology, A.J.d.S.T. and M.S.S.; software, A.J.d.S.T.; validation, L.S.S., G.A.e.S.F. and A.J.d.S.T.; formal analysis, E.P. and G.R.; investigation, M.S.S.; resources, L.S.S. and A.J.d.S.T.; data curation, M.S.S. and G.A.e.S.F; writing-original draft preparation, L.S.S. and M.S.S.; writing—review and editing, G.A.e.S.F. and L.S.S.; visualization, G.R. and E.P.; supervision, G.A.e.S.F.; project administration, G.A.e.S.F.; funding acquisition, G.A.e.S.F., G.R. and E.P. All authors have read and agreed to the published version of the manuscript.

Funding: This research was funded by the Embrapa Café-Consórcio Pesquisa Café, project approved no 234/2019, the National Council for Scientific and Technological Development (CNPq), the Research Support Foundation of the State of Minas Gerais (FAPEMIG), the Coor-dination for the Improvement of Higher Education Personnel (CAPES), the Federal University of Lavras (UFLA) and University of Firenze (UniFI).

Conflicts of Interest: The authors declare no conflict of interest.

\section{References}

1. Chain-Guadarrama, A.; Martínez-Salinas, A.; Aristizábal, N.; Ricketts, T.H. Ecosystem services by birds and bees to coffee in a changing climate: A review of coffee berry borer control and pollination. Agric. Ecosyst. Environ. 2019, 280, 53-67. [CrossRef]

2. Marin, D.B.; Alves, M.D.C.; Pozza, E.A.; Belan, L.L.; Freitas, M.L.D.O. Multispectral radiometric monitoring of bacterial blight of coffee. Precis. Agric. 2018, 20, 959-982. [CrossRef]

3. Belan, L.L.; Junior, W.C.D.J.; De Souza, A.F.; Zambolim, L.; Filho, J.C.; Barbosa, D.H.S.G.; Moraes, W.B. Management of coffee leaf rust in Coffea canephora based on disease monitoring reduces fungicide use and management cost. Eur. J. Plant Pathol. 2020, 156, 683-694. [CrossRef]

4. Júnior, P.P.; Moreira, B.C.; Silva, M.D.C.S.D.; Veloso, T.G.R.; Stürmer, S.L.; Fernandes, R.B.A.; Mendonca, E.; Kasuya, M.C.M. Agroecological coffee management increases arbuscular mycorrhizal fungi diversity. PLoS ONE 2019, 14, e0209093. [CrossRef]

5. U.S. Department of Agriculture. Coffee: World Markets and Trade; U.S. Department of Agriculture, U.S. Government Printing Office: Washington, DC, USA, 2021.

6. Santana, L.; Ferraz, G.; Cunha, J.; Santana, M.; Faria, R.; Marin, D.; Rossi, G.; Conti, L.; Vieri, M.; Sarri, D. Monitoring Errors of Semi-Mechanized Coffee Planting by Remotely Piloted Aircraft. Agronomy 2021, 11, 1224. [CrossRef]

7. Cadenas, J.; Garrido, M.; Martínez-España, R.; Guillén-Navarro, M. Making decisions for frost prediction in agricultural crops in a soft computing framework. Comput. Electron. Agric. 2020, 175, 105587. [CrossRef]

8. Murugan, D.; Garg, A.; Singh, D. Development of an Adaptive Approach for Precision Agriculture Monitoring with Drone and Satellite Data. IEEE J. Sel. Top. Appl. Earth Obs. Remote Sens. 2017, 10, 5322-5328. [CrossRef]

9. Paccioretti, P.; Córdoba, M.; Balzarini, M. FastMapping: Software to create field maps and identify management zones in precision agriculture. Comput. Electron. Agric. 2020, 175, 105556. [CrossRef] 
10. Yost, M.A.; Kitchen, N.R.; Sudduth, K.A.; Massey, R.E.; Sadler, E.J.; Drummond, S.T.; Volkmann, M.R. A long-term precision agriculture system sustains grain profitability. Precis. Agric. 2019, 20, 1177-1198. [CrossRef]

11. Alves, E.A.; Queiroz, D.M.; Pinto, F.A.C. Cafeicultura de precisão. In Boas Práticas Agrícolas na Produção de Café; Zambolim, L., Ed.; UFV: Viçosa, Brazil, 2007; p. 234. ISBN 8560027157.

12. Kouadio, L.; Deo, R.C.; Byrareddy, V.; Adamowski, J.F.; Mushtaq, S.; Nguyen, V.P. Artificial intelligence approach for the prediction of Robusta coffee yield using soil fertility properties. Comput. Electron. Agric. 2018, 155, 324-338. [CrossRef]

13. Andrade, A.D.; Ferraz, G.A.E.S.; De Barros, M.M.; Faria, R.D.O.; Da Silva, F.M.; Sarri, D.; Vieri, M. Characterization of the Transverse Distribution of Fertilizer in Coffee Plantations. Agronomy 2020, 10, 601. [CrossRef]

14. Ferraz, G.A.E.S.; Da Silva, F.M.; De Oliveira, M.S.; Custódio, A.A.P.; Ferraz, P. Variabilidade espacial dos atributos da planta de uma lavoura cafeeira. Rev. Cienc. Agron. 2017, 48, 81-91. [CrossRef]

15. Dos Santos, L.M.; Ferraz, G.A.E.S.; Barbosa, B.D.D.S.; Diotto, A.V.; Maciel, D.T.; Xavier, L.A.G. Biophysical parameters of coffee crop estimated by UAV RGB images. Precis. Agric. 2020, 21, 1227-1241. [CrossRef]

16. Barros, M.M.; Volpato, C.E.S.; Silva, F.C.; Palma, M.A.Z.; Spagnolo, R.T. Avaliação de um sistema de aplicação de fertili-zantes a taxa variável adaptado à cultura cafeeira. Coffee Sci. 2015, 10, 223-232.

17. Koutsos, T.M.; Menexes, G.C.; Dordas, C.A. An efficient framework for conducting systematic literature reviews in agricultural sciences. Sci. Total Environ. 2019, 682, 106-117. [CrossRef]

18. Pollock, M.; Fernandes, R.M.; Becker, L.A.; Featherstone, R.; Hartling, L. What guidance is available for researchers conducting overviews of reviews of healthcare interventions? A scoping review and qualitative metasummary. Syst. Rev. 2016, 5, 1-15. [CrossRef]

19. Sharma, G.; Bansal, P. Partnering Up: Including Managers as Research Partners in Systematic Reviews. Organ. Res. Methods 2020, 1-30. [CrossRef]

20. Souza, V.H.S.; Dias, G.L.; Santos, A.A.R.; Costa, A.L.G.; Santos, F.L.; Magalhães, R.R. Evaluation of the interaction between a harvester rod and a coffee branch based on finite element analysis. Comput. Electron. Agric. 2018, 150, 476-483. [CrossRef]

21. Centobelli, P.; Cerchione, R.; Chiaroni, D.; Del Vecchio, P.; Urbinati, A. Designing business models in circular economy: A systematic literature review and research agenda. Bus. Strat. Environ. 2020, 29, 1734-1749. [CrossRef]

22. Coman, M.A.; Marcu, A.; Chereches, R.M.; Leppälä, J.; Broucke, S.V.D. Educational Interventions to Improve Safety and Health Literacy Among Agricultural Workers: A Systematic Review. Int. J. Environ. Res. Public Health 2020, 17, 1114. [CrossRef]

23. Seuring, S.; Gold, S. Conducting content-analysis based literature reviews in supply chain management. Supply Chain Manag. Int. J. 2012, 17, 544-555. [CrossRef]

24. Daim, T.U.; Rueda, G.; Martin, H.; Gerdsri, P. Forecasting emerging technologies: Use of bibliometrics and patent analysis. Technol. Forecast. Soc. Chang. 2006, 73, 981-1012. [CrossRef]

25. Liu, W.; Gu, M.; Hu, G.; Li, C.; Liao, H.; Tang, L.; Shapira, P. Profile of developments in biomass-based bioenergy research: A 20-year perspective. Scientometrics 2013, 99, 507-521. [CrossRef]

26. Andrade-Valbuena, N.A.; Merigo-Lindahl, J.M.; Olavarrieta, S. Bibliometric analysis of entrepreneurial orientation. World J. Entrep. Manag. Sustain. Dev. 2019, 15, 45-69. [CrossRef]

27. Sharifi, A.; Simangan, D.; Kaneko, S. Three decades of research on climate change and peace: A bibliometrics analysis. Sustain. Sci. 2020, 16, 1079-1095. [CrossRef]

28. Mallett, R.; Hagen-Zanker, J.; Slater, R.; Duvendack, M. The benefits and challenges of using systematic reviews in international development research. J. Dev. Eff. 2012, 4, 445-455. [CrossRef]

29. Chain, C.P.; Dos Santos, A.C.; De Castro, L.G.; Prado, J.W.D. Bibliometric analysis of the quantitative methods applied to the measurement of industrial clusters. J. Econ. Surv. 2018, 33, 60-84. [CrossRef]

30. Pallottino, F.; Biocca, M.; Nardi, P.; Figorilli, S.; Menesatti, P.; Costa, C. Science mapping approach to analyze the research evolution on precision agriculture: World, EU and Italian situation. Precis. Agric. 2018, 19, 1011-1026. [CrossRef]

31. Velasco-Muñoz, J.F.; Aznar-Sánchez, J.A.; Batlles-Delafuente, A.; Fidelibus, M.D. Rainwater Harvesting for Agricultural Irrigation: An Analysis of Global Research. Water 2019, 11, 1320. [CrossRef]

32. Kane, D.A.; Rogé, P.; Snapp, S.S. A Systematic Review of Perennial Staple Crops Literature Using Topic Modeling and Bibliometric Analysis. PLoS ONE 2016, 11, e0155788. [CrossRef]

33. Madani, F.; Weber, C. The evolution of patent mining: Applying bibliometrics analysis and keyword network analysis. World Pat. Inf. 2016, 46, 32-48. [CrossRef]

34. Muhuri, P.K.; Shukla, A.K.; Abraham, A. Industry 4.0: A bibliometric analysis and detailed overview. Eng. Appl. Artif. Intell. 2019, 78, 218-235. [CrossRef]

35. Noyons, E.C.M.; Moed, H.F.; Luwel, M. Combining mapping and citation analysis for evaluative bibliometric purposes: A bibliometric study. J. Am. Soc. Inf. Sci. 1999, 50, 115-131. [CrossRef]

36. Börner, J.; Marinho, E.; Wunder, S. Mixing Carrots and Sticks to Conserve Forests in the Brazilian Amazon: A Spatial Probabilistic Modeling Approach. PLoS ONE 2015, 10, e0116846. [CrossRef]

37. Garfield, P.E. Citation indexes for science. A new dimension in documentation through association of ideast. Int. J. Epidemiol. 2006, 35, 1123-1127. [CrossRef]

38. Moed, H.F.; Markusova, V.; Akoev, M. Trends in Russian research output indexed in Scopus and Web of Science. Scientometrics 2018, 116, 1153-1180. [CrossRef] 
39. Bakkalbasi, N.; Bauer, K.; Glover, J.; Wang, L. Three options for citation tracking: Google Scholar, Scopus and Web of Science. Biomed. Digit. Libr. 2006, 3, 1-8. [CrossRef]

40. Pizzi, S.; Caputo, A.; Corvino, A.; Venturelli, A. Management research and the UN sustainable development goals (SDGs): A bibliometric investigation and systematic review. J. Clean. Prod. 2020, 276, 124033. [CrossRef]

41. Barbara, K.; Charters, S.; Budgen, D.; Brereton, P.; Mark, T.; Linkman, S.; Jørgensen, M.; Mendes, E.; Visaggio, G. Guidelines for performing Systematic Literature Reviews in Software Engineering. Version 2.3. Durham UK. 2007. Available online: https: / / citeseerx.ist.psu.edu/viewdoc/summary?doi=10.1.1.117.471 (accessed on 22 March 2021).

42. Nardi, P.; Di Matteo, G.; Palahi, M.; Mugnozza, G.S. Structure and Evolution of Mediterranean Forest Research: A Science Mapping Approach. PLoS ONE 2016, 11, e0155016. [CrossRef]

43. Van Eck, N.J.; Waltman, L. Software survey: VOSviewer, a computer program for bibliometric mapping. Scientometrics 2009, 84, 523-538. [CrossRef]

44. Van Eck, N.J.; Waltman, L. A Comparison of TwoTechniques for Bibliometric Mapping: Multidimensional Scaling and VOS Nees. J. Am. Soc. Inf. Sci. Technol. 2010, 61, 2405-2416. [CrossRef]

45. Merton, R. The sociology of science: An episodic memoir. In The Sociology of Science in Europe; Southern Illinois University Press: Carbondale, IL, USA, 1977; pp. 3-141.

46. Herwitz, S.; Johnson, L.; Dunagan, S.; Higgins, R.; Sullivan, D.; Zheng, J.; Lobitz, B.; Leung, J.; Gallmeyer, B.; Aoyagi, M.; et al. Imaging from an unmanned aerial vehicle: Agricultural surveillance and decision support. Comput. Electron. Agric. 2004, 44, 49-61. [CrossRef]

47. Chemura, A.; Mutanga, O.; Dube, T. Separability of coffee leaf rust infection levels with machine learning methods at Sentinel-2 MSI spectral resolutions. Precis. Agric. 2016, 18, 859-881. [CrossRef]

48. Sentelhas, P.C.; Gillespie, T.J.; Batzer, J.C.; Gleason, M.L.; Monteiro, J.E.B.A.; Pezzopane, J.; Pedro, M.J. Spatial variability of leaf wetness duration in different crop canopies. Int. J. Biometeorol. 2005, 49, 363-370. [CrossRef]

49. Silva, F.M.; De Souza, Z.M.; De Figueiredo, C.A.P.; Júnior, J.M.; Machado, R.V. Spatial Variability Of Chemical Attributes And Productivity In The Coffee Cultivation. Ciência Rural. 2007, 37, 401-407. [CrossRef]

50. Silva, F.M.; Souza, Z.M.; Figueiredo, C.A.P.; Vieira, L.H.D.S.; Oliveira, E. Spatial variability of chemical attributes and coffee productivity in two harvests. Cienc. Agrotecnol. 2008, 32, 231-241. [CrossRef]

51. Cordero-Sancho, S.; Sader, S.A. Spectral analysis and classification accuracy of coffee crops using Landsat and a topographicenvironmental model. Int. J. Remote Sens. 2007, 28, 1577-1593. [CrossRef]

52. Silva, S.D.A.; Lima, J.S.D.S.; da Silva, J.M.; Teixeira, M.M. Spatial variability of chemical attributes of an Oxisol under coffee cultivation. Rev. Bras. Ciência Solo. 2010, 34, 16-23. [CrossRef]

53. Ferraz, G.A.E.S.; da Silva, F.M.; Alves, M.D.C.; Bueno, R.D.L.; da Costa, P.A.N. Geostatistical analysis of fruit yield and detachment force in coffee. Precis. Agric. 2011, 13, 76-89. [CrossRef]

54. Ferraz, G.A.E.S.; Da Silva, F.M.; Carvalho, L.C.C.; Alves, M.D.C.; Franco, B.C. Spatial And Temporal Variability Of Phosphorus, Potassium And Of The Yield Of A Coffee Field. Eng. Agric. 2012, 32, 140-150. [CrossRef]

55. Armenta-Medina, D.; Ramirez-Delreal, T.A.; Villanueva-Vásquez, D.; Mejia-Aguirre, C. Trends on Advanced Information and Communication Technologies for Improving Agricultural Productivities: A Bibliometric Analysis. Agronomy 2020, $10,1989$. [CrossRef]

56. Sott, M.K.; Furstenau, L.B.; Kipper, L.M.; Giraldo, F.D.; Lopez-Robles, J.R.; Cobo, M.J.; Zahid, A.; Abbasi, Q.H.; Imran, M.A. Precision Techniques and Agriculture 4.0 Technologies to Promote Sustainability in the Coffee Sector: State of the Art, Challenges and Future Trends. IEEE Access 2020, 8, 149854-149867. [CrossRef]

57. Santana, L.S.; Ferraz, G.A.E.S.; Santos, L.M.; Maciel, D.A.; Barata, R.A.P.; Reynaldo, É.F.; Rossi, G. Vegetative vigor of maize crop obtained through vegetation indexes in orbital and aerial sensors images. Braz. J. Biosyst. Eng. 2019, 13, 195-206. [CrossRef]

58. Pivoto, D.; Waquil, P.D.; Talamini, E.; Finocchio, C.P.S.; Corte, V.; Mores, G.D.V. Scientific development of smart farming technologies and their application in Brazil. Inf. Process. Agric. 2018, 5, 21-32. [CrossRef]

59. Johnson, L.F.; Herwitz, S.R.; Lobitz, B.M.; Dunagan, S.E. Feasibility of monitoring coffee field ripeness with airborne multi-spectral imagery. Appl. Eng. Agric. 2004, 20, 845-849. [CrossRef]

60. Cruz-O'Byrne, R.; Piraneque-Gambasica, N.; Aguirre-Forero, S.; Ramirez-Vergara, J. Microorganisms in coffee fermentation: A bibliometric and systematic literature network analysis related to agriculture and beverage quality (1965-2019). Coffee Sci. 2020, 15, 1-14. [CrossRef]

61. Pabon, C.D.R.; Sánchez-Benitez, J.; Rosero, J.R.; Ramirez-Gonzalez, G.A. Coffee crop science metric: A review. Coffee Sci. 2020, 15, 1-11. [CrossRef]

62. Sales, F.O.; Marante, Y.; Vieira, A.B.; Silva, E.F. Energy Consumption Evaluation of a Routing Protocol for Low-Power and Lossy Networks in Mesh Scenarios for Precision Agriculture. Sensors 2020, 20, 3814. [CrossRef] [PubMed]

63. Marin, D.; Ferraz, G.; Guimarães, P.; Schwerz, F.; Santana, L.; Barbosa, B.; Barata, R.; Faria, R.; Dias, J.; Conti, L.; et al. Remotely Piloted Aircraft and Random Forest in the Evaluation of the Spatial Variability of Foliar Nitrogen in Coffee Crop. Remote Sens. 2021, 13, 1471. [CrossRef]

64. Oré, G.; Alcântara, M.S.; Góes, J.A.; Oliveira, L.P.; Yepes, J.; Teruel, B.; de Castro, V.L.B.; Bins, L.S.; Castro, F.; Luebeck, D.; et al. Crop Growth Monitoring with Drone-Borne DInSAR. Remote Sens. 2020, 12, 615. [CrossRef] 